\title{
Waste Material Ashes Used in Concrete
}

\author{
Ranjan Abraham, T.R. Neelakantan, C. Ramesh Babu
}

\begin{abstract}
Disposal problem of waste materials and excessive demand on naturally available resources due to rapid urban development has opened possibilities for use of waste materials in construction industry. Many waste materials are used in concrete as replacement to cement, fine aggregate, coarse aggregate and reinforcement. Here review of some waste materials, whose ash is used as partial replacement to cement in concrete, is presented. Different properties of fresh and hardened concrete, when admixed with ash of waste materials are reviewed. Concrete containing sugar cane bagasse ash, ground nut shell ash, rice husk ash, saw dust ash, and tobacco waste ash are reviewed. After review, it is observed that further studies are required on all waste ashes replacing cement, which will reveal more potential on their usage in concrete. Concrete containing ash of waste materials attained demanded strength within 5\% to $20 \%$ replacement.
\end{abstract}

Keywords : Waste materials, Ashes, Replacement of cement

\section{INTRODUCTION}

Concrete, mixture of cement, and aggregates, is prepared from natural based resources. Population increment and urban expansion demands huge quantity of natural resource usage in construction field, resulting in resource scarcity. The scarcity in materials motivated researchers to use, waste materials generated from industries, mining, household and agriculture. It is observed in India that wastes generated from various sources leads to disposal problems. Issue of contamination can be taken care of by use of wastes as construction materials, as land filling and reduce expenses towards building materials and ensure sustainability. Research on usage of ash of waste materials, as substitution for cement requires more research in terms of long-term durability of concrete. Relationship is established between concrete prepared using waste materials and green building rating systems after studies. Construction material is an important aspect in Current Green Building Rating system.

\section{ASHES OF WASTE MATERIALS USED IN CONCRETE}

Ashes of wastes used as substitution of cement in concrete are sugar cane bagasse ash, ground nut shell ash, rice husk ash, saw dust ash and tobacco waste ash. Major differences in them are the place from where they are procured and the process adopted in converting them to ash.

Revised Manuscript Received on December 5, 2019

* Correspondence Author

Ranjan Abraham*, Faculty, Ilahia College of Engineering \& Technology, Muvattupuzha, Kerala and Research Scholar, Kalasalingam Academy of Research and Education, Krishnankoil, India. Email: ranjanabraham@icet.ac.in

T.R. Neelakantan, Civil Engineering Department, Kalasalingam Academy of Research and Education, Krishnankoil, India. Email: neelakantan@klu.ac.in

C. Ramesh Babu, Civil Engineering Department, Kalasalingam Academy of Research and Education, Krishnankoil, India. Email: babussr@gmail.com
Sugarcane and rice husk are produced world-wide by burning to convert them into sugar cane bagasse ash and rice husk ash respectively. They are used as partial substitution to cement, and provides added pozzolanic property to concrete. Ground nut shells are burnt and converted into ash prior to use in concrete. Saw dust is generated by processing of raw wood by mechanical means in saw mill industry and burnt to produce ash. Tobacco wastes are collected from cigarette industries, burnt and ash is used as a substitute to binder in concrete. The review looks into workability and properties of concrete prepared by replacing cement in partial amount with ashes of waste materials.

\section{Sugarcane Bagasse Ash}

Fibrous residue of sugar cane after extraction of juice is "bagasse". It is used as fuel, which leaves behind 8-10\% of ash, known as sugar cane bagasse ash. Bagasse consists of approximately 50 percent cellulose, 25 percent hemi-cellulose and 25 percent lignin [1]. Sugar cane bagasse is available from sugar factories all over the world. It is partially used as fuel in sugar plants, but major portion is disposed as waste and unutilized. Controlled burning produces ash having amorphous silica, having pozzolanic properties. Sugar cane production is more than 1.50 billion tons worldwide. Around 10 million tons of sugarcane bagasse ash is disposed as waste material in India [2]. It is beneficial to be used as partial substitute to cement in concrete, avoid disposal issues and reduce consumption of cement.

\section{Groundnut Shell Ash}

Ground nut shell is available as agricultural farm waste in large quantities. Ground nut was first cultivated in South Africa and Brazil. Later it's cultivation spreaded to other parts of world including America, Asia, and north western Argentina. The outer part of ground nut is ground nut shell. It is considered as a solid waste over a period of years. Utilization of ground nut shell in construction industry solves pollution related issues and increases financial base of agriculturists and encourage them to boost production. Ground nut shell is used in developing roofing materials, replacement to cement and as fine aggregate in concrete [3].

\section{Sawdust Ash}

Sawdust is used in manufacture of particle board. It is used as fuel too. It is treated as a hazardous object in manufacturing industries, due to high degree of flammability [4]. Saw dust is used for making light weight concrete in recent past [5]. Sawdust ash is a good choice as cement substitute to concrete. It can reduce disposal problems considerably and reduce cement usage [6]. Many experts have studied behaviour of saw dust ash in concrete and observed that sawdust possessed exclusive characteristics, which make it superior above other materials [7]. 


\section{Ricehusk Ash}

Rice husk is the waste obtained from shell of rice grains during the processing of rice grains. Rice husk is a waste material which creates environmental pollution. Because of low nutrition it is unsuitable for edible purpose. In a few countries; it is used as fuel in rice processing plants and electricity generation plants, in order to reduce volume of rice husk waste. Many experts used ash of rice husk as cement substitute in concrete. Studies on properties of self compacting concrete, using rice husk ash are also done [8]. Use of rice husk ash in S.C.C. reduces unit weight, flowability, porosity, water absorption, compressive strength and cost of S.C.C. [9].

\section{Tobacco Waste Ash}

Tobacco waste is produced annually in large quantity by processing and cigarette making industry. Studies were conducted to evaluate possibility in usage of waste tobacco material ash in concrete. Properties were studied with different replacement levels of tobacco waste ash [10]. On density basis, lightweight concrete is categorized into three classes. Low density, used for isolation purpose, middle density, used in production of briquette and carrier lightweight, has application in building foundations and supports. Owing to lower density and compressive strength, tobacco waste is an ideal isolation material.

\section{CHEMICAL PROPERTIES OF WASTE ASHES}

Properties of materials are presented in Table I.

Table-I Chemical Composition

\begin{tabular}{|c|c|c|c|c|c|}
\hline $\begin{array}{c}\text { Chemical } \\
\text { Composit } \\
\text { ion } \\
(\%)\end{array}$ & $\begin{array}{c}\text { Sugarcane } \\
\text { Bagasse } \\
\text { Ash }\end{array}$ & $\begin{array}{c}\text { Ground } \\
\text { nut } \\
\text { Shell } \\
\text { Ash }\end{array}$ & $\begin{array}{c}\text { Saw } \\
\text { dust } \\
\text { Ash }\end{array}$ & $\begin{array}{c}\text { Rice } \\
\text { husk } \\
\text { Ash }\end{array}$ & $\begin{array}{c}\text { Tobacco } \\
\text { waste } \\
\text { Ash }\end{array}$ \\
\hline $\mathrm{SiO}_{2}$ & 68.42 & 41.42 & 65.74 & 88.32 & 18.44 \\
\hline $\mathrm{Al}_{2} \mathrm{O}_{3}$ & 5.81 & 11.75 & 5.67 & 0.46 & 4.89 \\
\hline $\mathrm{Fe}_{2} \mathrm{O}_{3}$ & 0.23 & 12.60 & 3.39 & 0.67 & 2.80 \\
\hline $\mathrm{CaO}$ & 2.66 & 11.23 & 1.85 & 0.67 & 37.67 \\
\hline $\mathrm{P}_{2} \mathrm{O}_{5}$ & 1.48 & 1.71 & 0.00 & 0.59 & 3.70 \\
\hline $\mathrm{MgO}^{2}$ & 0.67 & 3.51 & 3.72 & 0.44 & 9.86 \\
\hline $\mathrm{SO}_{3}$ & 4.83 & 0.44 & 2.54 & 0.00 & 1.94 \\
\hline $\mathrm{Na}_{2} \mathrm{O}$ & 0.00 & 1.02 & 0.92 & 0.12 & 0.45 \\
\hline $\mathrm{K}_{2} \mathrm{O}$ & 0.00 & 11.89 & 12.67 & 2.91 & 11.44 \\
\hline $\mathrm{TiO}_{2}$ & 0.00 & 0.63 & 0.00 & 0.00 & 0.40 \\
\hline $\begin{array}{c}\mathrm{Loss} \text { of } \\
\text { Ignition }\end{array}$ & 15.90 & 3.80 & 3.50 & 5.82 & 8.41 \\
\hline
\end{tabular}

Chemical analysis of sugarcane bagasse collected from Maroli Sugar factory, Gujarat, was conducted in Pollution Laboratories, Surat and the results are tabulated in Table-1 [2]. The chemical composition is dominated by silicon dioxide $\left(\mathrm{SiO}_{2}\right)$.

Chemical analysis was carried out on samples of G.S.A. to study the composition and it was observed that G.S.A. contains most of the compounds having binding properties necessary for concrete work [3]. Even though total volume of $\mathrm{SiO}_{2}, \mathrm{Al}_{2} \mathrm{O}_{3}$ and $\mathrm{Fe}_{2} \mathrm{O}_{3}$ was less than $70 \%$, amount of $\mathrm{MgO}$ was much higher than minimum recommended level.
Chemical analysis of S.D.A. showed that total volume of $\mathrm{SiO}_{2}, \mathrm{Al}_{2} \mathrm{O}_{3}$ and $\mathrm{Fe}_{2} \mathrm{O}_{3}$ was more than $70 \%$, indicating that it is a good pozzolanic material in accordance with ASTM standards $[4,5,6,7]$.

Rice husk collected from paddy field of Kula Selangor, Malaysia was burnt in laboratory for one day using Ferrocement furnace. The chemical composition is dominated by silicon dioxide $\left(\mathrm{SiO}_{2}\right)$ and total volume of $\mathrm{SiO}_{2}, \mathrm{Al}_{2} \mathrm{O}_{3}$ and $\mathrm{Fe}_{2} \mathrm{O}_{3}$ was found to be more than $70 \%$, which make it a good pozzolanic material as per ASTM standards [8].

Chemical analysis of T.W.A. revealed that it contains considerable amount of $\mathrm{CaO}, \mathrm{SiO}_{2}, \mathrm{~K}_{2} \mathrm{O}, \mathrm{MgO}$ and $\mathrm{Al}_{2} \mathrm{O}_{3}$ [10]. Total volume of $\mathrm{SiO}_{2}, \mathrm{Al}_{2} \mathrm{O}_{3}$ and $\mathrm{Fe}_{2} \mathrm{O}_{3}$ was found to be less than $70 \%$, which is minimum limit to be considered as a pozzolanic material. Still they possess pozzolanic property, but less than normally used pozzolanic materials. It is observed to produce $100 \%$ compressive strength of OPC, which is due to filler effect.

As per ASTM standards, total volume of $\mathrm{SiO}_{2}, \mathrm{Al}_{2} \mathrm{O}_{3}$ and $\mathrm{Fe}_{2} \mathrm{O}_{3}$ should not be less than $70 \%$ for a natural pozzolana material. Sugarcane bagasse ash, saw dust ash, rice husk ash satisfy above requirement. Even though others don't satisfy above requirement, they are found to produce strength equivalent to that of samples prepared with OPC alone, which is attributed to filler effect produced by them. American Standards ASTM C618 standards and Brazilian standards (NBR 12653) limits loss of ignition to 6\%. It is seen that ground nut shell ash, saw dust ash, rice husk ash satisfy the requirements of above mentioned standards.

\section{MIX PROPORTIONS ADOPTED FOR STUDY}

Researchers tried to achieve different strengths (targetted strength) from $20 \mathrm{MPa}$ to $40 \mathrm{MPa}$ using different types of cement, agricultural waste ash types, level of replacement of cement and water-cement ratio.

Rahane (2017) targeted strengths of M20, M30 \& M40 by replacement of up to $25 \%$ of cement in concrete mix with sugarcane bagasse ash. Mix design was done as per IS10262 and OPC of 53 grade was used for study [1].

Raijiwala (2017) targeted strength of M25 by replacing 5 $\%$ of cement in concrete mix with sugar cane bagasse ash. Mix design was done as per IS10262 and OPC 53 grade cement was used for study [2].

Nwofor (2012) targeted strength of M20 by replacing up to $40 \%$ of cement in concrete mix with groundnut shell ash. Mix design was done as per ACI code and OPC was used for study [3].

Anchaleyu (2017) targeted strength of M25 by replacing up to $15 \%$ of cement in concrete mix with saw dust ash. Mix design was done as per IS10262 and OPC of 53 grade was used for study [4].

Mujedu (2014) targeted strength of M20 by replacing up to $50 \%$ of cement in concrete mix with saw dust ash. Mix design was done as per British standards and OPC was used for study [5].

Malik (2015) targeted strength of M25 by replacing up to $20 \%$ of cement in concrete mix with saw dust ash. Mix design was done as per IS10262 standards and OPC of grade 43 was used for study [6]. 
Raheem (2012) targeted strength of M20 by replacing up to $25 \%$ of cement in concrete mix with saw dust ash. Mix design was done as per IS10262 standards and OPC was used for study [7].

Habeeb (2009) targeted strength of M40 by replacing up to $20 \%$ of cement in concrete mix with rice husk ash. Mix design was done as per British standards and OPC was used for study [8].

Marthong (2012) targeted strength of M30 by replacing up to $40 \%$ of cement in concrete mix with rice husk ash. Mix design was done as per British standards and OPC was used for study [9].

Moreeno (2018) targeted strength of M30 by replacing up to $40 \%$ of cement in concrete mix with tobacco waste ash. Mix design was done as per British standards and OPC was used for study [10].

\section{OPTIMUM REPLACEMENT LEVELS}

\section{A. Sugarcane Bagasse Ash}

Studies proved that optimum replacement for cement with sugarcane bagasse ash is $10 \%$. Beyond that level, compressive strength development started decreasing. Increase in substitution ratio showed decrease in compressive strength values, with indicates that filler effect is predominant up to $10 \%$ ash substitution. Combined effect of physical and chemical processes is responsible for increase in compressive strength values. Physical action is due to high specific surface area of S.C.B.A. and chemical action is due to Pozzolonic reaction between calcium hydroxide (Lime) and silica $\left(\mathrm{SiO}_{2}\right)$. Hydration of silica $\left(\mathrm{SiO}_{2}\right)$ in alkaline environment is responsible for increase in compressive strength.

\section{B. Groundnut Shell Ash}

Studies proved that the optimum replacement for cement with groundnut shell ash is $10 \%$. Beyond that, compressive strength development started decreasing. There is a general increase in strength with age, which is due to the slow pozzolanic reaction. Increase in percentage replacement lead to lower strength, which is due to the lower cementing property of GSA compared to OPC.

\section{Sawdust Ash}

Studies proved that optimum replacement of cement with saw dust ash is from 5 to $10 \%$. $5 \%$ substation is recommended to achieve maximum strength gain. Beyond that level, compressive strength started decreasing. Substitution of cement with SDA demanded less water to maintain required workability. Compressive strength of samples increased with curing age.

\section{Ricehusk ash}

Studies proved that optimum replacement of cement with rice husk ash is from 10 to $20 \%$. Beyond that level, compressive strength started decreasing. Addition of RHA decreased workability and demanded more water for workability.

\section{E. Tobacco waste wash}

Studies proved that the optimum replacement for cement with tobacco waste ash is $10 \%$. Beyond that level, compressive strength started decreasing. Addition of
Tobacco waste ash decreased workability and demanded more water for workability.

\section{FRESH PROPERTIES}

It was observed that ash based concrete developed maximum slump at $0 \%$ replacement and slump decreased at higher replacement levels. This was due to higher water absorption of ash materials, which reduced flowability of mixes at same water binder ratio. Concrete became unworkable at higher levels of replacement of ash. Ground nut shell ash mixed concrete showed lower slump value compared to others, due to absorption of more water. Compaction factor started reducing with increase in replacement levels of cement with ash, which is also attributed to the high water absorption.

\section{COMPRESSIVE STRENGTH}

Strength development is due to the combined effect of relative fineness and Pozzolanic activity of ashes. Concrete using sugarcane bagasse ash showed an increase in compressive strength at $10 \%$ replacement than control concrete, but further increase decreased strength. Compressive strength can be improved by increasing curing period. Replacement of ground nut shell ash produced compressive strength increase at 5\% replacement than control concrete. Strength of concrete containing saw dust ash showed increase at 5\%,10\% and $15 \%$ replacement. Concrete containing $20 \%, 25 \%$ and $30 \%$ replacement produced lower strengths. Rice husk ash developed maximum strength at $10 \%$ replacement. Higher water requirement lead to more porosity and reduced strength. Rick husk ash was able to fill micro voids in cement particles in a better way.

\section{FUTURE RECOMMENDATIONS}

Based on literature review done, following studies are recommended in future.

A thorough investigation of engineering properties of concrete based on ash of waste materials is required to be conducted and compared with properties of conventionally made concrete.

Only hardened property which was studied is compressive strength. Properties like tensile strength, flexural strength, and elastic modulus can also be studied and results can be compared with conventionally prepared concrete.

Before selecting any concrete for usage, durability study is mandatory. Limited data on durability have been reported so far on concrete prepared with ash of waste materials as partial replacement to cement. Therefore study on durability properties of can be done.

Further studies are required on thermal behaviour of concrete using ash of waste materials as partial replacement to cement

\section{CONCLUSIONS}

Sugarcane bagasse ash, rice husk ash and saw dust ash can be utilized as pozzolans as their combined percentage of $\mathrm{SiO}_{2}, \mathrm{Al}_{2} \mathrm{O}_{3}$, and $\mathrm{Fe}_{2} \mathrm{O}_{3}$ is above $70 \%$ 


\section{Waste Material Ashes Used in Concrete}

It is observed that, required compressive strength of concrete was achieved by $5 \%$ to $20 \%$ of replacement of cement, depending on type of ash.

Samples prepared by replacement of cement with ash showed lower compressive strength compared to control mix samples, in initial days. The strength gradually increased with age of curing, due to pozzolanic action of ash. Addition of RHA increased setting time, but within the range recommended for pure cement. Rate of attaining strength depends on the grade of cement used. Replacement of cement with RHA improved durability to sulphate environment. Concrete prepared with saw dust ash can be utilized for normal concreting works. Substitution of cement with ashes of waste materials reduces disposal problem of waste and consumption of cement and $\mathrm{CO}_{2}$ emission.

\section{REFERENCES}

1. S. Bangar Sayali, N. Phalke Shubhangi, Y. Gawade Anjali, S. Tambe Rutuja, A.B. Rahane, "A review paper on replacement of cement with bagasseash", International Journal of Engineering Sciences and Management, Vol 1, pp-127-131, January - March 2017.

2. J.A Patel, D.B. Raijiwala, "Experimental study on use of sugarcane bagasseash in concrete by partially replacement with cement", International Journal of Innovative Research in Science, Engineering and Technology, Vol 4, pp-2228-2232, April 2015

3. T.C. Nwofor, S. Sule, "Stability of groundnut shell ash (GSA) ordinary portland cement (OPC) concrete in Nigeria" Advances in Applied Science Research, Pelagia Research Library, Vol 3, pp-2283-2287, April 2012

4. Kunchala Anjaneyulu, "Partial replacement of cement concrete by waste Materials", International Journal of Engineering Development and Research, Vol 5, pp-1374-1382, 2017

5. K.A. Mujedu,, S.A. Adebara, I.O. Lamidi, "The use of corn cob ash and saw dust ash as cement replacement in concrete works", The International Journal Of Engineering And Science, Vol 3, pp-22-28, April 2014

6. Mohammad Iqbal Malik, Syed Rumysa Jan, Junaid Ahmad Peer, Syed Azhar Nazir, Khubbab Fa Mohammad, "Partial replacement of cement by saw dust ssh in concrete - A sustainable approach", International Journal of Engineering Research and Development, Vol 11, pp-48-52, February2015

7. Raheem, B.S. Olasunkanmi, C.S. Folorunso, "Saw dust ash as partial replacement for cement in concrete" Organization, technology and management in construction . an international journal, Vol 3, pp-474-480, March 2012

8. Ghassan Abood Habeeb, Hilmi Bin Mahmud, , 2010, "Study on properties of rice husk ash and it's use as cement replacement material", Materials Research, Vol 13, pp-185-190, March 2010

9. C.Marthong, "Effect of rice husk ash (RHA) as partial replacement of cement on concrete properties", International Journal of Engineering Research \& Technology, Vol 1, pp-1-7, August 2012

10. Paalo Moren, Rafael Fragozo, Sergio Vesga - Mauricio Gonzalez, Liliana Hernandez, Ivan D. Gamboa, Jose Delgado, "Tobacco waste ash: a promising supplementary cementitious material”,International Journal of Energy and Environmental Engineering, Vol 1, pp-499-504, May 2018

\section{AUTHORS PROFILE}

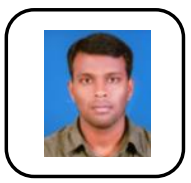

Ranjan Abraham, Research Scholar in Kalasalingam Academy of Research and Education, completed his M. Tech. in Civil Engineering from Mahatma Gandhi University, Kottayam, Kerala. He has more than 14 years of teaching experience. His areas of interest are Structural Engineering and Concrete Technology

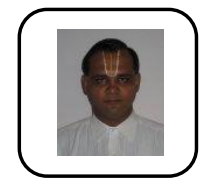

Dr. T.R. Neelakantan is a Senior Professor in Civi Engineering and Director - Accreditation and Ranking at Kalasalingam Academy of Research and Education, Tamilnadu. He obtained his Ph.D. degree in Civil Engineering from Anna University in the year 1998. His working experiences are from Anna University, IIT-Madras, SASTRA Deemed University and the University of Kentucky,
Lexington, USA. He published more than 60 articles in reputed journals, and handled many government and private funded projects both in India and USA.

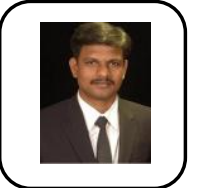

Ramesh Babu, Chokkalingam completed his Ph.D. from IIT Chennai. He has more than ten years of experience in teaching and research. His areas of research includes pervious concrete, geopolymer concrete, and high volume flyash concrete. 